\title{
MINAT PESERTA DIDIK DALAM BEROLAHRAGA PADA MASA PANDEMI COVID - 19 KELAS VIII SMP NEGERI 5 SINGARAJA TAHUN AJARAN 2020/2021
}

\author{
Komang Wibawa ${ }^{1}$, H. Wahjoedi ${ }^{2}$, I Ketut Semarayasa ${ }^{3}$ \\ Prodi Pendidikan Jasmani Kesehatan dan Rekreasi \\ Jurusan Pendidikan Olahraga \\ Fakultas Olahraga dan Kesehatan \\ Universitas Pendidikan Ganesha \\ Singaraja-Bali
}

Email: komangwibawa392@gmail.com, wahjoedi@undiksha.ac.id, ketut.semarayasa@undiksha.ac.id

\begin{abstract}
ABSTRAK
Jenis penelitian ini bertujuan untuk mengetahui minat pesertat didik kelas VIII SMP Negeri 5 Singaraja dalam berolahraga di masa pandemi covid-19. Penelitian ini adalah deskriptif kuantitatif dengan jenis penelitian survei. Populasi penelitian ini adalah seluruh peserat didik kelas VIII SMP Negeri 5 Singaraja dengan jumlah keseluruhan 202 orang siswa. Sampel penelitian menggunakan non random sampling yaitu quota sampling dengan besaran $15 \%$ dari total populasi sehingga jumlah sample dalam penelitian ini berjumlah 80. Data dianalisis menggunakan statistik deskriptif kuantitatif dengan kategori interval. Hasil penelitian ini pada faktor ekstrinsik minat peserta didik kelas VIII SMP Negeri 5 Singaraja dalam berolahraga pada masa pandemi covid-19 mendapatkan skor $73 \%$ dalam interval kategori dinyatakan sangat tinggi. Pada faktor intrinsik minat peserta didik kelas VIII SMP Negeri 5 Singaraja dalam berolahraga pada masa pandemi covid-19 mendapat skor $75 \%$ dalam interval kategori dinyatakan sangat tinggi. Dari kedua indikator pada variabel, minat peserta didik kelas VIII SMP Negeri 5 Singaraja memperoleh skor $74 \%$. Pada interval katagori sangat tinggi . melalui temuan yang sudah di jelaskan di atas, dapat disimpulkan bahwa minat berolahraga pada masa pandemi covid-19 peserta didik kelas VIII di SMP Negeri 5 Singaraja termasuk dalam katagori tinggi. Dengan demikian, peneliti menyarankan agar peserta didik dapat mempertahankan minatnya dalam berolahraga pada masa pandemi covid-19 sehingga meningkatkan imunitas tubuh serta menjaga pola hidup sehat dan tubuh yang bugar walau di lakukan di rumah.
\end{abstract}

\section{Kata-kata kunci :Minat, Berolahraga, Pandemi covid-1}

\begin{abstract}
This type of research aims to determine the interest of grade VIII students of State Junior High School 5 Singaraja in exercising during the Covid-19 pandemic. This research is descriptive quantitative with survey research type. The population of this study were all class VIII students of State Junior High School 5 Singaraja with a total of 202 students. The research sample used non-random sampling, namely quota sampling with a size of $15 \%$ of the total population so that the number of samples in this study amounted to 80. Data were analyzed using quantitative descriptive statistics with interval categories. The results of this study on extrinsic factors of interest in class VIII students of State Junior High School 5 Singaraja in exercising during the Covid-19 pandemic got a score of 73 in the category interval stated as very high. In the intrinsic factor, the students' interest in class VIII State Junior High School 5 Singaraja in exercising during the Covid-19 pandemic got a score of 75 in the category interval stated as very high. Of the two indicators on the variable, the interest of class VIII students of State Junior High School 5 Singaraja obtained a score of 74. At the category interval the data is very high. Suggestions from researchers are that students continue to carry out sports activities during the Covid19 pandemic so that their endurance is stronger. The conclusion from the description above is that the interest in exercising for VIII grade students of State Junior High School 5 Singaraja during the Covid19 pandemic was high. This is known through the data described above. Thus, researchers suggest that students can maintain their interest in exercising during the Covid-19 pandemic so as to increase body immunity and maintain a healthy lifestyle and a fit body even at home.
\end{abstract}


Key word: interest, exercise, Covid-19 pandemic

\section{PENDAHULUAN}

Masyarakat Indonesia saat ini masih kurang menyadari akan pentingnya hidup sehat. Hal ini terjadi karena kurangnya animo/minat dan apresiasi masyarakat terhadap olahraga. Tapi melihat beberapa bulan ke belakang masyarakat Indonesia termasuk diwilayah-wilayah terpencil animo/minat masyarakat dalam berolahraga sangatlah tinngi di karenakan saat ini Negara Indonesia sedang dilanda pandemi virus covid-19 yang membuat semua masyarakat tidak bisa beraktivitas seperti normal dikarena pemerintah mengeluarkan peringatan untuk bekerja dirumah, beribadah dirumah, belajar dirumah dan pemerintah juga menganjurkan untuk menjaga kesehatan diri sendiri melalui berolahraga dirumah yang dimana berolaharaga pada masa pandemi covid-19 dapat membuat imonitas tubuh lebih kuat untuk melawan penyakit yang datang. Dalam menjaga kesehatan diri untuk menjaga imonitas tubuh supaya tetap terjaga dimasa pandemi covid-19 banyak aktifitas olahraga yang bisa di lakukan dirumah ataupun diluar rumah dalam menjaga imunitas tubuh.

Penyakit yang ditimbulkan oleh Novel Corona Virus 2019 ( Covid-19) adalah penyakit yang menular yang disebabkan oleh SARS-COV-2, salah satu jenis koronavirus dimana penyakit ini telah menjadi pademi ditahun 2019-2020. Infeksi menyebar dari satu orang ke orang lain melalui percikan (droplet) dari saluran pernapasan yang sering dihasilkan saat batuk atau bersin. Sejak merebaknya pandemi yang disebabkan oleh virus corona di Indonesia, banyak cara yang dilakukan oleh pemerintah untuk mencegah penyebarannya. Dengan persebaran pandemi covid-19 yang begitu cepat melanda dunia hal ini menyebabkan dosen dan mahasiswa mau tidak mau berjuang dengan keadaan ini. Situasi yang sebelumnya proses pembelajaran berlangsung dengan tatap muka, dengan bimbingan langsung bertemu fisik dengan proses dikelas menjadi suatu hal yang tidak bisa dilaksanakan lagi.

\section{KAJIAN TEORI \\ Minat}

Minat merupakan pergerakan awal untuk seseorang melakukan kegiatan awal demi suatu tujuan yang diinginkan. Hal ini menggambarkan seseorang memiliki minat dalam dirinya untuk melakukan kegiatan atau tindakan maka dia akan mencapai keinginanya, tetapi jika sebaliknya maka seseorang tersebut tidak akan bisa mencapai keinginan atau cita-citanya. Sejalan dengan pendapat di ungkapkan oleh Djali (2007:99), menyatakan minat yang besar (keinginan yang kuat) terhadap suatu merupakan modal untuk bisa mencapai tujuan

Slameto (2015:180) menyatkan bahwa minat adalah suatu rasa lebih suka dan ketertarikan pada suatu hal atau aktivitas tanpa ada yang menyuruh. Setiap individu mempunyai keinginan untuk berhubungan dengan suatu yang ada di sekitar lingkunganya baik itu tentang suatu hal maupun aktivitas

Minat akan terlihat dengan baik jika mereka bisa menemukan objek yang disukai dengan tepat sasaran serta berkaitan langsung dengan keinginan tersebut. Minat juga harus memiliki objek yang jelas untuk mempermudah kemana arah seseorang harus bersikap dan menuju objek yang tepat. (Sadirman.1990)

Dari beberapa pendapat diatas dapat disimpulkan bahwa minat adalah suatu sifat yang ada di dalam diri seseorang untuk melakukakn kativitas tertentu dengan menggunakan hati atau tidak dalam paksaan orang lain untuk melakukakn seseuatu aktivitas apapun iti kegiatanya.

\section{Hakikat Olahraga}

Menurut Bannet dkk. (dalam Harsuki, 2003), "olahraga (sport) adalah aktivitas jasmani yang dilembagakan yang peraturannya 16 ditetapkan bukan oleh pelakunya atau secara eksternal sebelum melakukan aktivitas tersebut. 
Menurut Coakley (dalam Harsuki, 20003) mendefinisikan olahraga sebagai berikut: sport is an institutionalized competitive activity than involves vigorous physical exertion or the use of relatively complex phsycal skill, by individual whose participation is motived by combination of the intrinsic satisfication associated with the activity it self and the external reward earned through participation. Dari kutipan gersebut menerangkan bahwa olahraga adalah kegiatan kompetitif yang dilembagakan serta melibatkan usaha fisik atau penggunaan keterampilan fisik yang relatif kompleks, oleh individu yang partisipasinya didorong oleh kombinasi dari kepuasan dari dalam diri yang berkaita dengan aktifitas itu sendiri dan penghargaan dari luar/eksternal yang diperoleh melalui partisipasi.

Wilkwerson dan Dodder (dalam Harsuki, 2003) mengemukakan tujuh fungsi olahraga, sebagai berikut :

1. Pelepasan emosi. Olahraga memberikan cara untuk menyatakan emosi dan mengundurkan ketegangan, jadi bertindak sebagai satu katub keselamatan dan kataris untuk meniadakan kecendrungan agresif.

2. Menunjukan identitas. Olahraga memberikan cara untuk dikenal orang dan menunjukan kualitas diri

3. Kontrol sosial. Olahraga memberikan cara untuk mengontrol orang dalam satu masyarakat bila ada penyimpangan perilaku

4. Sosialisasi. Olahraga dapat berperan sebagai satu cara untuk terjadi kontak sosial sesama penggemar olahraga.

5. Agen Perubahan. Olahraga menghasilkan perubahan sosial, pola prilaku baru, dan menjadi satu faktor yang mengubah jalan sejarah. Umpannya, olahraga memungkinkan untuk berinteraksi dari semua jenis manusia dan untuk mobilitas ke atas berdasarkan kemampuan.

6. Semangat Kolektif. Olahraga menciptakan semangat kebersamaan yang membuat orang bersatu untuk mencari tujuan.

7. Sukses. Olahraga memberikan perasaan berhasil, baik sebagai pemain maupun penonton, bila seorang pemain atau regu meraih sukses.

Berdasarkan pendapat diatas dapat disimpulkan bahwa olahraga merupakan aktivitas yang mencakup semua aktivitas manusia yang ditujukan untuk mencapai tujuan atau cita-cita. Olahraga memiliki cakupan kompleks di masyarakat meliputi semua usia.

\section{Peserta Didik}

Peserta didik ialah salah satu komponen manusiawi yang menempati posisi sentral dalam proses belajarmengajar. Peserta didik ialah sebagai pihak yang ingin meraih cita-cita meiliki tujuan dan kemudian ingin mencapainya secara optimal. Peserta didik menjadi faktor penentu, sehingga dapat mendapat mempengaruhi segala sesuatu yang diperlukan untuk mencapai tujuan belajarnya.

Menurut kamus besar Bahasa Indonesia pengertian peserta didik berarti orang, anak yang sedang berguru (belajar, bersekolah). Sedangkan menurut pasal 1 ayat 4 UU RI No. 20 tahun 2013. Mengenai sistem pendidikan nasional, dimana peserta didik adalah anggota masyarakat yang berusaha mengembangkan diri mereka melalui proses pendidikan pada jalur dan jenjang dan jenis pendidikan.

\section{Pandemi Covid-19}

Masyarakat dunia tengah diresahkan dengan adanya wabah Corona Virus Disease ( Covid-19) yang menjadi sebuah pandemi. Seluruh dunia kini disibukkan dengan berbagai upaya pencegahan Covid-19 untuk menahan lonjakan pasien positif karena hingga saat ini masih belum ditemukan obat maupun vaksinnya. Selain itu dengan adanya virus Covid-19 pemerintah membuat beberapa kebijakan untuk menghentikan penyebaran wabah ini, seperti melakukan lockdown di daerah yang sudah termasuk kedalam zona merah penyebaran virus, lalu physical quarantine untuk mnghindari penyebaran virus secara kontak fisik. Novel Corona Virus 2019 (N- 
Covid 19 ) yang biasa disebut dengan virus corona adalah penyakit menular yang disebabkan oleh SARS-COV-2, salah satu jenis corona virus dimana penyakit ini telah menjadi pandemic ditahun 2019-2020. Gejala corona virus muncul dalam 2-14 hari setelah paparan ditandai dengan gejala gangguan pernapasan akut seperti demam, batuk, dan sesak napas, pada kasus berat menyebabkan pneumonia

\section{METODE PENELITIAN}

Penelitian ini termasuk kedalam jenis penelitian deskriptif dengan pendekatan kuantitatif. Metode yang digunakan dalam pengumpulan data penelitian ini menggunakan metode survei, sedangkan

\section{HASIL DAN PEMBAHASAN}

\section{Hasil}

Berdasarkan analisis data dapat dideskripsikan bahwa siswa yang memiliki motivasi sangat setuju untuk berolahraga selama pandemic covid-19 sebanyak 320 orang. Namun, jumlah yang sama ditunjukan oleh siswa yang memiliki motivasi setuju sebanyak 749 orang. jenis survei yang digunakan yaitu survei kuisioner yang dijawab oleh peserta didik. Populasi dalam penelitian ini adalah seluruh peserta didik kelas VIII SMP Negeri 5 Singaraja, dengan jumlah 203 orang. Sementara sampel dipilih berdasarkan convenience sampling yang ini diambil $15 \%$ dari populasi penelitian, dimana total sampelnya adalah sebanyak 80 orang.

Berdasarkan pemaparan diatas, pengumpulan data dalam penelitian ini menggunakan kuisioner, dimana kuisioner yang disebarkan terdapat 20 pernyataan yang terdiri dari 16 pernyataan positif dan 4 pernyataan negatif. Jawaban peserta didik diklasifikasikan yaitu sangat setuju (SS), Setuju (S), Tidak Setuju (TS) dan Sangat Tidak Setuju (STS).
Perbedaan jumlah yang signifikan ditunjukan oleh siswa yang memiliki motivasi tidak setuju sebanyak 439orang siswa dan siswa yang memiliki motivasi sangat tidak setuju 98 orang siswa

Tabel 4. Hasil Analisis Deskriptif

\begin{tabular}{ccccc}
\hline No. & Indikator & $\begin{array}{c}\text { Banyak } \\
\text { siswa }\end{array}$ & $\begin{array}{c}\text { Rata- } \\
\text { rata }\end{array}$ & Katagori \\
\hline 1. & Faktor Instrinsik & 80 & 75 & Tinggi \\
\hline 2. & Faktor Ekstrinsik & 80 & 73 & Tinggi \\
\hline
\end{tabular}

20 Pernyataan pada indikator intrinsik memperoleh skor $75 \%$, sedanglan pada 20 pernyataan indikator ekstrinsik mendapatkan skor $73 \%$. Angka tersebut bila dikonversikan dalam tabel skala penilaian kategori berada pada kategori tinggi, untuk mengetahui hasil analisis data pada kedua indikator pada variabel minat peserta didik dalam mengikuti pembelajaran PJOK pada masa pandemi covid-19 maka rumus yang digunakan yaitu:

$$
=\frac{X 1+X 2}{2}
$$

$$
\begin{aligned}
& =\frac{75+73}{2} \\
& =74
\end{aligned}
$$

Angka tersebut apabila dilihat pada skala penilaian kategori terrgolong pada kategori tinggi.

\section{Pembahasan}

Berdasarkan tujuan utama dari penelitian ini yaitu untuk mengetahui motivasi siswa dalam berolahraga dimasa pandemic covid-19 di SMP Negeri 5 Singaraja diperoleh hasil bahwa siswa memiliki motivasi berolahraga selama 
pandemic covid-19. Hal ini ditunjukan dengan hasil yang diperoleh setelah pengumpulan data. Perhitungan yang dilakukan menunjukan angka 74 yang berada pada kategori tinggi. Hal tersebut mengindikasikan bahwa siswa dari SMP Negeri 5 Singaraja memiliki motivasi yang tinggi untuk berolahraga yang dipengaruhi oleh faktor intrinsik dan ekstrinsik.

Selain itu, hasil tersebut mengindikasikan bahwa siswa memiliki keinginan dalam menjaga kebugaran dan imunitas tubuh selama pandemic covid-19. Hasil dari penelitian ini memiliki hasil 75\% di bagian instrinsik yang sama dengan penelitian yang telah dilakukan oleh Kasim, Muhammad. 2011.

Penelitian yang memiliki hasil yang sama yaitu Pungki Indarto, Nur Subekti, Eko Sudarmanto. 2018. "Pengukuran Tingkat Minat Dengan Bakat Mahasiswa Pendidikan Olahraga Universitas Muhammadiyah juga menyatakan bahwa siswa dari kedua sekolah memiliki minat yang sama tingginya dalam mengikuti pemeblajaran dan aktivitas dalam pendidikan jasmani, olahraga, dan kesehatan. Data tersebut menunjukan di angka 74 yang berada di katagori tinggi tersebut mengindikasikan bahwa siswa dikedua sekolah memiliki minat dan kesadaran yang tinggi terhadap pentingnya berolahraga.

\section{PENUTUP \\ Simpulan}

Berdasarkan hasil analisis data yang menggunakan deskriptif kuantitatif, maka pembelajaran PJOK pada masa pandemi covid-19.

\section{DAFTAR RUJUKAN}

Djaali.2007. Psikologi Pendidikan. Jakarta: PT Bumi Perkasa.Harsuki. 2003. Perkembangan Olahraga Terkini (Kajian Para Akbar). Jakarta: Raja Grafindo Persada.

Herlina dan Maman Suherman. 2020. "Potensi Pembelajaran Pendidikan Jasmani Olahraga dan Kesehatan (PJOK) di Tengah Pandemi Corona Virus Disease dapat di simpulkan bahwa Minat Peserta Didik Dalam Mengikuti Pembelajaran PJOK Pada Masa Pandemi Covid-19 di Kelas VIII SMP N 5 Singaraja adalah tinggi Saran

Berdasarkan simpulan penelitian tersebut, adapun saran yang dapat diberikan adalah sebagai berikut :

1. Bagi peserta didik

Peserta didik diharapkan untuk mempertahankan minatnya yang sudah tinggi dalam mengikuti pembelajaran PJOK pada masa pandemi covid-19, dengan harapan melalui aktivitas gerak yang ada dalam pembelajaran PJOK, kesehatan peserta didik tetap terjaga dan terhindar dari penularan covid-19 dengan meningkatkan daya tahan tubuh.

\section{Bagi peneliti}

Bagi peneliti lain yang berminat mengadakan penelitian deskriptif kuantitatif tentang survei minat peserta didik dalam mengikuti pembelajaran PJOK pada masa pandemi covid-19, agar menjadikan hasil penelitian ini sebagai salah satu referensi untuk meneliti dalam lingkup yang lebih luas, sehingga diperoleh sumbangan ilmu yang lebih baik dan sesuai dengan perkembangan zaman dan diperoleh dalam penelitian lebih objektif.

\section{Bagi Guru}

Guru diharapkan untuk lebih memperhatikan lagi cara agar dapat mempertahankan minat peserta didik yang tergolong sangat baik dalam mengikuti

$\begin{gathered}\text { (Covid)-19 di } \\ \text { Dasar". }\end{gathered}$ Terdapat $\begin{gathered}\text { Sekolah } \\ \text { pada }\end{gathered}$
$\begin{gathered}\text { http://jurnal.untad.ac.id/jurnal/index.php/P } \\ \frac{\text { JKR/article/view/16186 }}{\text { tanggal } 17 \text { Juli 2020) }} \text { (diakses pada }\end{gathered}$

Kanca, I Nyoman. 2010. Metode Penelitian Pengajaran Pendidikan Jasmani dan Olahraga. Singaraja: Jurusan Pendidikan Jasmani, Kesehatan, dan Rekreasi. Fakultas Olahraga dan Kesehatan Universitas Pendidikan Ganesha Singaraja.Undiksha. 
Kasim, Muhammad. 2011. "Pentingnya Motivasi dan Minat Terhadap Manajemen Kinerja Guru dalam Pelaksanaan Pembelajaran Pendidikan Jasmani, Olahraga dan

Kesehatan". Terdapat pada http://jurnal.untad.ac.id/jurnal/index.php/ac $\underline{\text { ademica/article/download/228 } \quad \text { 5/1478 }}$ (diakses pada tanggal 17 Juli 2020)

Susanto, Nugroho. 2020. "\{engaruh Virus Covid 19 Terhadap Bidang Olahraga Di Indonesia" Terdapat pada

http://stamina.ppi.unp.ac.id/index.php/JST/ article/view/491 (diakses pada tanggal 17 Juli 2020)

Pungki Indarto, Nur Subekti, Eko Sudarmanto. 2018. "Pengukuran Tingkat Minat Dengan Bakat Mahasiswa Pendidikan Olahraga Universitas Muhammadiyah Surakarta" TerdapatPada https://journal.unesa.ac.id/index.php/jses/ article/view/3204 (diakses pada tanggal 17 Juli 2020)

Putrantana, Angga Bramansta. 2017. "Pembentukan Karakter Siswa Sekolah Dasar Melalui Permainan Tradisional pada Pendidikan Jasmani, Olahraga dan Kesehatan". Terdapat pada http://pasca.im.ac.id/conferences/index.ph p/por/article/view/622 (diakses pada tanggal 17 Juli 2020)

Rawes Budiarta. 2018. Minat dan Motivasi Peserta Didik Terhadap Ekstrakurikuler woodball di Sekolah Menengah Atas Negeri 2 Banjar Kabupaten Buleleng Tahun Pelajaran 2017/2018. Fakultas Olahraga dan Kesehatan. Universitas Pendidikan Ganesha.

Slameto. 2015. Metodelogi Penelitian \& Inovasi Pendidikan. Salatiga:Cipta

Sugiyono. 2009. Metodelogi Penelitian Kuantitatif, Kualitatif Dan R\&D, Bandung: Alfabet. 